\title{
From Yeats to Friel: Irish Mythology through Arts and Science in the 20th century
}

\section{Frédéric Armao}

\section{(2) OpenEdition \\ 1 Journals}

\section{Electronic version}

URL: http://journals.openedition.org/etudesirlandaises/4842

DOI: 10.4000/etudesirlandaises.4842

ISSN: 2259-8863

\section{Publisher}

Presses universitaires de Rennes

\section{Printed version}

Date of publication: 15 June 2016

Number of pages: 115-125

ISBN: 978-2-7535-5091-9

ISSN: 0183-973X

\section{Electronic reference}

Frédéric Armao, "From Yeats to Friel: Irish Mythology through Arts and Science in the 20th century », Études irlandaises [Online], 41-1 | 2016, Online since 15 June 2018, connection on 01 May 2019. URL: http://journals.openedition.org/etudesirlandaises/4842; DOI : 10.4000/etudesirlandaises.4842 


\title{
From Yeats to Friel: Irish Mythology through Arts and Science in the $20^{\text {th }}$ Century
}

\author{
Frédéric ARMAO \\ Université de Toulon
}

Abstract

The present article analyzes the use of Irish mythology (and more specifically of "Celtic" festivals) in the course of the $20^{\text {th }}$ century by two Irish authors, William Butler Yeats and Brian Friel. This use, which one may at first think dictated solely by artistic considerations, turns out to be more profound and symptomatic of Irish culture - this Irishness which is so often connected to political and/or religious values. The study of the notion of "science" and its impact on the culture and customs of modern Ireland will prove helpful since the issue was tackled directly by both authors, be it as a complement or a potential rival to the Irish way(s).

Keywords: Celtic festivals, Irish festivals, folklore, mythology, science, Yeats, Friel

\section{Résumé}

Le présent article analyse l'utilisation faite au cours du XXe siècle de la mythologie irlandaise et plus particulièrement du cas des fêtes dites "celtiques " par deux auteurs irlandais, William Butler Yeats et Brian Friel. Cette utilisation, que l'on pourrait imaginer au premier abord dictée par des raisons purement artistiques, se révèle plus profonde et symptomatique de la culture irlandaise, cette Irishness, souvent étroitement liée à des valeurs politiques etlou religieuses. La thématique de la "science " et son impact sur la culture et les moeurs de l'Irlande moderne sera un élément qui permettra d'enrichir notre étude, la problématique ayant été abordée directement par les deux auteurs en complément, et parfois en opposition, à la " tradition " irlandaise.

Mots clés : fêtes celtiques, fêtes irlandaises, folklore, mythologie, science, Yeats, Friel

There is not one single way to practice one's religion or faith, even within a group of people sharing the same beliefs: if anything, spirituality is protean. When practiced freely, spirituality is a personal endeavor and, despite the fact that it is rooted in the history of a people and regulated by a precise - and sometimes strictly official - creed, the spirituality felt and exercised by a being is unique, peculiar, specific and profoundly connected to their own personal history. Conversely, spirituality corresponds to the discovery of an inner path which cannot exist without a surrounding environment: the more complex and troublesome the environment, the more peculiar the inner path. 
Modern Irish history is obviously a troubled one. Even without taking into consideration the recent world economic crisis, the various tragic events that stood out in the making of the young Republic in the $20^{\text {th }}$ century considerably influenced its population ${ }^{1}$. The difficult relationship with its British neighbors throughout the centuries and the rivalry on Irish soil between two major branches of Christianity, Protestantism and Catholicism, led to the creation of a specific Irish culture - or sometimes several Irish cultures ${ }^{2}$ - which has been studied by a large number of scholars in the past decades ${ }^{3}$.

Even if Irish history has been tremendously influenced by Catholicism and obviously Protestantism, another factor should not be neglected and had a real impact upon the construction of Irish identity: what is referred to as the Celtic past of the island. Throughout recent history and still today this Celtic past has been, without a doubt, used, exploited by a portion of the Irish population, i.e. artists, politicians and thinkers. Whether the intention to manipulate the past and therefore infuse a new sense of "Celticism" in Ireland is deliberate or not is yet to be determined: there is obviously not one single answer and each occurrence ought to be analyzed and understood separately.

The example of the so-called "Celtic Festivals" is truly interesting as regards the importance of spirituality and the regulation of both the sacred and secular Irish year. Those festivals were, up to the second part of the $20^{\text {th }}$ century, a really important feature of Irish folk-life, especially, but not exclusively, in the countryside and some of the most remote regions of the island.

In this article we will look at two specific examples of the use, or rather "reinventing", of those ancient festivals in the $20^{\text {th }}$ century: first, we will see how William Butler Yeats managed to incorporate the Celtic system of beliefs in a specific part of his body of work; the second example will unite mythology and science: the play Dancing at Lughnasa, which was written in 1990 by Brian Friel, will provide a most interesting instance of the evolution of old myths and their adaptation to a modern world.

These two symptomatic examples taken together will hopefully shed a new light on the use made of spirituality and its adaptation to the arts (in the Yeats example) or its assimilation with science (in the Friel example) through one single set of beliefs: the Celtic Festivals. Moreover, it will enable us to tackle the issue of identity and will therefore raise a rather singular question: to what extent and

1. The term "modern" will be used throughout this paper to refer to the period that saw the rise of "modernity" (progress and technology in the broader sense possible and their impact on culture, philosophy, politics and society as a whole) in the Western world and more specifically in Ireland and/or will be used in contrast to what is believed to be "the old ways", i.e. ancient traditions.

2. André Guillaume, L'Irlande, une ou deux nations?, Paris, PUF, 1987.

3. See for instance Terence Brown, Ireland, a Social and Cultural History, 1922-1985, London, Fontana, 1981 or Gregory Castle, Modernism and the Celtic Revival, Cambridge, Cambridge University Press, 2001. 
under what conditions may a (reconstructed?) spirituality influence the (re-)creation of identity in this modern Irish context?

\section{The Irish Festivals: a Reminder}

There used to be (and still are, to a certain extent) four major festivals which punctuated the Irish year and divided it into four quarters. Each quarter began with a specific festival:

[This] is one of the great facts of the Celtic past and the strength with which it was rooted in consciousness and has survived to this day is remarkable. The four feasts were identified (when and how we cannot tell) with November first, February first, May first, and August first of the Julian calendar ${ }^{4}$.

Those four feasts took the name of Samhain, Imbolc, Beltaine and Lughnasa respectively. Samhain was probably the most important festival of all as it apparently marked the beginning of the New Year and of the winter season. Without going into too much detail, it was also associated with a large number of traditions, most of those being linked to the rural activities of farmers and agricultural workers. For instance, fairs were organized throughout the country, the transhumance ended and all the crops were supposed to have been harvested at Samhain: failing to do so meant bad luck for the rest of the year ${ }^{5}$. Incidentally, the November festival ${ }^{6}$ was a period where the gates between the world of the living and the "Other World" were thought to open: for this reason, a number of superstitions were linked with apparitions, strange deaths or abductions, witchcraft and spells as well as mischiefs performed by fairies, which were in fact feared in Ireland as they were often associated with the people of the Other World, i.e. with death ${ }^{7}$.

Six months later, the other major Irish festival, Beltaine, marked the beginning of summer: it was also the time farmers chose to send their cattle to the pastures (the same cattle that would come back at Sambain) and agricultural workers stopped sowing their seeds. The first days of May were the second time of the

4. Máire MacNeill, The Festival of Lughnasa, 1962, Dublin, Comhairle Bhéaloideas Eireann, 1982, p. 1.

5. Françoise Le Roux and Christian Guyonvarc'h, Les Fêtes Celtiques, Rennes, Ouest-France, 1995, chap. 1.

6. Obviously, the original Celtic system was not connected with the Julian calendar. The festivals were most likely originally held around the midpoint between equinoxes and solstices (maybe taking into account the phases of the moon in the process). See Donatien Laurent, "Le Juste milieu. Réflexion sur un rituel de circumambulation millénaire : la troménie de Locronan", in Marie Louise Tenèze (ed.), Tradition et Histoire dans la culture populaire. Rencontres autour de l'ceuvre de Jean-Michel Guilcher, Grenoble, Centre Alpin et Rhodanien d'Ethnologie, 1990. See also Frédéric Armao, "La Charnière de mai: Beltaine, fête celtique ou fête irlandaise?", Ollodagos, vol. XXVIII, Brussels, Actes de la Société Belge d'Études Celtiques, 2013, p. 61-128.

7. See for instance Walter Yeeling Evans-Wentz, The Fairy-Faith in Celtic Countries, 1911, Mineola, New York, Dover Publications, 2002, p. 332-57. 
year when the world of the living and the dead were traditionally connected: the same apparitions and spells were feared by the rural population. Summer began with Beltaine and this festival was both a time for fear (fear of witchcraft, fairies, bad crops, poor weather...) and hope (hope for a plentiful year, good luck and good crops, hope of finding love or avoiding ageing, as many spells were aimed at stopping the effects of time passing). The most famous tradition was the passing of cattle between two fires on the Eve of the $1^{\text {st }}$ of May: those fires were supposed to purify and protect the animals from any harm or diseases for the next six or twelve months ${ }^{8}$.

Imbolc is a specific case as little is known about it, except for the fact that it marked the beginning of spring and was also connected with rural activities. As the feast is sometimes referred to as Saint Brigid's Day, the connection with the Christian saint, and/or a Christianized Celtic counterpart of the saint, is accepted by most researchers?.

In contrast, the festival of Lughnasa has been exceptionally well documented since the seminal work of Máire MacNeill thoroughly analyzed both its folklore and mythology. As we only mean here to remind our reader of the importance of those four feasts, we will simply mention the fact that Lughnasa marked the beginning of harvest and that the celebration of fall was associated in Ireland with a huge number of rural traditions and superstitions, fairs, festive assemblies and pilgrimages ${ }^{10}$.

All four festivals have been heavily Christianized throughout the centuries. Beltaine and Lughnasa were, for instance, associated with the Virgin Mary (the month of May has been dedicated to the mother of Jesus for at least seven centuries and the month of August is linked with the Christian Feast of the Assumption). The offerings that were originally made to the ancient pagan gods - the name Lughnasa derives from the Celtic god Lugh - were later dedicated to the Christian God and/or Mary. Furthermore, instead of forbidding or fighting pagan traditions, the Irish clergy often blessed the crops and the cattle on the date of the ancient festivals so that the feasts slowly became a syncretic form of celebrations borrowing from both the Celtic and Christian traditions ${ }^{11}$ : to that extent, they became essentially Irish, that is to say unique in content and form, taking from both the Celtic past of the island and the belief and practices of the "new religion". The fact that the Christianized Celtic festivals had gradually become a part

\footnotetext{
8. Patricia Lysaght, "Bealtaine: Irish Maytime Customs and the Reaffirmation of Boundaries », Boundaries and Thresholds, Woodchester, Thimble Press, 1993, p. 28-43 and Frédéric Armao, op. cit. or "The Women of Bealtaine: from the Maiden to the Witch", Cosmos 25, Ritual Year 4, 2009, p. 71-82.

9. Seamas O' Cathain, The Festival of Brigit, Blackrock, D.B.A. Publications, 1995.

10. Máire MacNeill, op. cit..

11. Ibid. Chap. 4 for example. See also Françoise Le Roux and Christian Guyonvarc'h, op. cit.
} 
of the identity of the Irish (rural) people paved the way for a rather singular use and exploitation of those celebrations: the artistic (and to some extent political) one.

\section{Yeats and the example of Beltaine}

William Butler Yeats was extremely interested in Irish folklore and mythology; this is particularly true and visible in his early work. This early interest and his involvement part in the "Celtic revival", that is to say a renewed awareness of ancient Celtic belief and traditions which occurred in the late $19^{\text {th }}$ century and the early $20^{\text {th }}$ century, undoubtedly defines a large part of his work and explains his motivation for preserving and hence redeeming Irish customs ${ }^{12}$. The political use he made of those ancient traditions and customs has often been studied ${ }^{13}$ : a true revivalist, Yeats was not only nostalgic for the old ways and what he believed to be an "authentic" peasantry; he believed in the inherent superior quality of those old ways, as they were supposed to reflect the ancient wisdom of the Irish people in all its alleged purity and assumed originality:

His interest in the purity and preeminence of a folk culture can be credited in large measure to a belief in the innate spiritualism and mysticism of the Irish peasantry ${ }^{14}$.

This rather romantic and primitivist view of folklore prevents us from considering Yeats as a perfectly reliable folklorist: the Nobel Prize winner was probably too intimately involved to prove a scientific and dependable ethnographer - even if his compilations are still worth studying, as long as one bears in mind his probable bias. The use he has made of old Irish traditions seems even more interesting and worth commenting upon as its clear political undertone sheds a new light on the writer's activism and raison d'être at the turn of the century. We will here focus on one specific example: the very peculiar use Yeats has made of Beltaine, the Irish festival that was held in early May.

Even though Yeats believed that the Irish rural and lower classes were the keepers of ancient traditions, he believed that the upper class was probably the only one to be refined enough to truly understand the deep meaning of ancient customs and be the worthy heirs of these old beliefs ${ }^{15}$. This led the "poet of Irishness" to create the Irish Literary Theatre in 1899 - which is the precursor to

12. Gregory Castle, op. cit., p. 41.

13. Ibid., p. 40-97.

14. Ibid., p. 41.

15. See for instance Seán O Tuama. Repossessions: Selected essays in the Irish Literary Heritage, Cork, Cork UP, 1995, p. 220 and G.J. Watson, Irish Identity and the Literary Revival: Synge, Yeats, Joyce and O'Casey, Washington D.C., Catholic U of America P, 1979, p. 98. 
the Ambarclann Naisiunta na hÉireann, or National Theatre of Ireland in Dublin. The idea was to present Irish plays that would focus on the roots of Irish folklore and myths and present them to an enlightened audience. The Protestant Yeats certainly fought imperialism and colonialism and believed that one of the ways to consolidate the culture of the Irish people was to spread it through all means possible - and Irish plays were surely one of those means.

The opening of the Irish Literary Theatre on 8-9 May 1899 was accompanied by the first issue of a theatrical pamphlet which was sold to the audience. This pamphlet, which was described as "The Organ of the Irish Literary Theatre" and which included the programme of the theatre, took the name of Beltaine. This specific name was chosen by Yeats to

stress the Irishness of the venture as well as confound his English critics, who would be able neither to translate nor to pronounce it $^{16}$.

In other words, the very name of Beltaine - which is indeed pronounced /bo:ItJanə/ by most Gaelic speakers and /beltein/ by English natives - was chosen by Yeats to represent Irishness as a whole. In the first edition of Beltaine (the pamphlet) the poet explained the purpose of his newly created venue:

The Irish Literary Theatre will attempt to do in Dublin something of what has been done in London and Paris; it will produce, somewhere about the old festival of Beltaine, at the beginning of every spring, a play founded upon an Irish subject ${ }^{17}$.

The fact that he chose the beginning of May to present old traditions to the audience of the theatre may therefore be understood as a way to prolong and respect ancient customs; plays dealing with Ireland and her past were to be shown at a fit time - and Beltaine being an major ancient festival of Ireland, the date definitely matched that definition.

For the reasons mentioned earlier, we will forgive the error of Yeats, who associated the festival of May the beginning of spring when most (if not all) primary and secondary sources attest that it corresponded to the beginning of summer. We will remember the political and intellectual significance acknowledged by the poet: Beltaine and the Irish Literary Theatre were actually attempts to preserve Irishness. He continues:

16. John Kelly and Ronald Schachard (ed.), The Collected Letters of W.B. Yeats: Volume Three, 1901-1924, Oxford, Oxford University Press, 1997, p. 250.

17. Mary Fitzgerald and Richard Finneran, (ed.), The Collected Works of W.B. Yeats, Volume VIII, The Irish Dramatic Movement, New York, Scribner, 2003, p. 143. 
The plays will differ from those produced $[. .$.$] in London and in$ Paris, because times have changed, and because the intellect of Ireland is romantic and spiritual rather than scientific and analytical ${ }^{18}$.

This vision, which seems to abruptly oppose "spirituality" to "science", seems to reflect the romantic state of mind of the author. Yeats had clearly modern(ist) views when it came to politics - his fight against imperialism and colonialism being a rather telling example - or art: his theatrical work has often been described as avant-garde ${ }^{19}$. However, his relationship with science and the agriculture/ industry dichotomy seems rather conservative to our contemporary perspective; it is in fact simply profoundly romantic, that is to say, in this case, linked with an inalienable and self-confessed primitivism.

Two years later, on May $21^{\text {st }} 1901$, Yeats wrote to Lady Gregory that the next issue of Beltaine "ought to come quite early this year" and that it "should be a Gaelic propaganda paper this time and might sell really well ${ }^{20 "}$. They also both agreed that any profits would be given to the Gaelic League - a major association promoting the Irish language and culture that was closely linked with nationalism. In other words, Beltaine had become in a couple of years not only an instrument for Irishness but also, to some extent, a Nationalist tool. The pamphlet Beltaine was renamed Sambain in October 1901,

because our plays this year are in October, and because our Theatre is coming to an end in its present shape ${ }^{21}$.

Sambain (the Irish festival opening winter celebrated in early November) was to be published until 1906. The name change did not alter the content - that is, supporting and fostering Irishness - and the profits of the pamphlet were actually given to the Gaelic League ${ }^{22}$.

Beltaine (and Samhain), as they were used by Yeats, mirrored his belief in the celebrated past of Ireland. Far from the accuracy of the folklorist, his work mainly aimed at glorifying Irish traditions and Irishness as a whole; the pure and "authentic" spiritual past of the island became a tool of propaganda. Indeed, Yeats was not only a primitivist romantic; in his view, the Celtic revival was a means and not an end, a powerful political device rather than a mere subject of study. The upper class was to be educated and had to understand the rural past of Ireland but only because more knowledge, more spirituality meant more "identity" and, to some

18. Ibid., p. 144.

19. Jacqueline Genet, Le Théâtre de W.B. Yeats, Paris, Septentrion, 1995, p. 15.

20. Mary Fitzgerald and Richard Finneran, op. cit., p. XVIII.

21. Ibid., p. 167.

22. Ibid. 
extent, more intellectual independence from the imperialist and colonialist British world.

\section{圈 Dancing at Lughnasa with Friel}

Far from being purely political or steeped in partisan ideals, our second example nonetheless remains quite remarkable because of its uniqueness and the way it is handled by the author. Dancing at Lughnasa is a play written by Brian Friel in 1990, a date which roughly corresponds to a second Celtic revival, even though the existence of such a second revival as a coordinated movement is quite debatable.

This semi-autobiographical play unfolding in the summer of 1936 in the rural County of Donegal, more specifically in the fictional village of Ballybeg, was originally presented in the aforementioned National Theatre of Ireland and was adapted as a film, eight years later, under the direction of Pat O'Connor and starring Meryl Streep.

The storyline is about five sisters and a child living on their family farm and battling against poverty in a country gradually evolving from its rural traditional past to a changing present embracing industrialization and science - modernity. As a matter of fact, one of the main threads of the play involves the apparition of science in the Irish country life - a form of science which changed and disrupted the old ways of the peasantry. Friel mentions this several times in the play and the theme was largely taken up in the O'Connor adaptation: as far as the film is concerned, we could mention the different shots of various harvesting machines which seem to replace the human workforce in the field; this is also underlined by the fact that the story takes place in summer and evolves around the time of Lughnasa which was traditionally closely connected to harvest. Moreover, the family is directly affected by industrialization as Agnes and Rose, two of the sisters, lose a part of their revenue to a brand new glove factory close to their homes:

Vera McLaughlin arrived and explained to Agnes and Rose why she couldn't buy their hand-knitted gloves any more. Most of her home knitters were already working in the new factory and she advised Agnes and Rose to apply immediately. The Industrial Revolution had finally caught up with Ballybeg ${ }^{23}$.

But the best example of the new science profoundly changing the ways of the old Irish protagonists is to be found at the beginning of both the play and the feature film: the family has bought their first wireless radio set.

23. Brian Friel, Dancing at Lughnasa, London, Faber and Faber, 1990, Act II, p. 59. 
We got our first wireless set that summer - well, a sort of a set; and it obsessed us. We called it "Lugh" after the old pagan god of the Harvest and his festival was Lughnasa, a time of music and dance ${ }^{24}$.

We got our first wireless set that summer - well, a sort of a set; and it obsessed us. And because it arrived as August was about to begin, my Aunt Maggie - she was the joker of the family - she suggested we give it a name. She wanted to call it Lugh after the old Celtic God of the Harvest. Because in the old days August the First was Lá Lughnasa, the feast day of the pagan god, Lugh; and the days and weeks of harvesting that followed were called the Festival of Lughnasa ${ }^{25}$.

Even though the association of the radio set with an "old Celtic God" is presented as a joke, the family seems obsessed with the new device: it is often compared to a magic appliance ("the sheer magic of the radio ${ }^{26 ")}$ and the word "voodoo" is in fact mentioned a number of times throughout the play in connection with Lugh; furthermore, the radio set stands as a proof that "things [are] changing too quickly before [the protagonist's] eyes ${ }^{27}$ ".

The word "voodoo" is in itself quite interesting for at least two reasons. First of all, it looks as if the magic of ancient rituals and traditions is replaced by the magic of science; hence the naming of the radio Lugh seems, to that extent, a little more than a simple joke. Second, one of the characters of the play is an Irish priest who, after some years spent in Africa, comes back to the family farm kept by his five sisters, his head filled with strange visions of African magic and spells. The character of Father Jack is a link not only between Irish and African paganism but also between pagan ways and the Catholic faith. Finally, the main character, Michael (a projection of the author) establishes a clear connection between Father Jack and science, more specifically their wireless radio set:

When I cast my mind back to that summer of 1936, these two memories - of our first wireless and of Father Jack's return - are always linked ${ }^{28}$.

In other words, the coming of this priest, steeped in both Catholicism and Paganism, is unambiguously connected to the arrival of Lugh, the "scientific" radio device with a traditional "spiritual" name.

Those three concepts - Paganism, Catholicism and science - are actually at the heart of both the play and the film. To that extent, a discussion between Father Jack and two of the sisters is quite telling. The three characters are trying to fix

24. From the introduction sequence of the O'Connor adaptation, distributed by Sony Pictures Classics, 1998.

25. Brian Friel, op. cit., Act I., p. 1.

26. Ibid., p. 2.

27. Ibid.

28. Ibid. 
Lugh, which keeps malfunctioning. After some time, the radio works again and plays music:

$$
\begin{aligned}
& \text { Jack - A miracle! } \\
& \text { Kate - It's no miracle, Jack. It is science! } \\
& \text { Magie - It's not science Kate, it's the god of Lughnasa. } \\
& \text { Kate - Pagan nonsense celebrating the feast of Lughnasa. This is the } \\
& \text { month of August, the feast of Our Lady's Assumption into Heaven }{ }^{29} \text { ! }
\end{aligned}
$$

This direct confrontation between Paganism (the miracle of Lugh finally playing music), science (supported by Kate who, surprisingly, is also a faithful Christian believer) and Catholicism (the Catholic priest and the character of Kate who provides a reminder that the Assumption is the be-all and end-all of the month of August) is not only unexpected and amusing: it is most of all revealing of the fact that the characters are torn between their old Irish traditions, the prevailing Catholic religion - both crucial in defining Irish identity - and science, the newcomer.

All the characters will eventually "dance at Lughnasa", therefore symbolically liberating themselves from their difficult lives and accepting, for a brief moment, their new and changing existence. O'Connor even made it the climax of his film: towards the end of the movie, Lugh is repaired and the device is playing traditional Irish music; one after the other, the characters surrender to the rhythmic and joyful tune and they all dance a most traditional group dance. Even the very Catholic Kate, who clutches her Bible under her arm for some time, gives in and joins the dance: she forgets about her strict views of religion and returns to her traditional Irish roots. Yet, she does so through science, as music is played by a modern device with an old mythological name: Lugh. In other words, science is federative - and magic - enough to unite the whole family; it is the vector of popular customs (in this case, Irish dance and music) and, indirectly, of pagan ways $-\mathrm{a}$ fact which is obviously underlined by the name given to the appliance.

The use of old Celtic festivals, and more generally both folklore and mythology, in connection with arts and science in Ireland appears to be quite peculiar. Paganism is supposed to be the old "original" Irish way; Christianity (especially but not exclusively Catholicism) the more conventional one. And science, the newcomer of the early $20^{\text {th }}$ century, could not be accepted if it did not include or at least embrace its two predecessors, giving birth in a way to a remarkable form of Irish syncretism. For this reason, Yeats thought the intellect (or better yet the spirit?) of Ireland was not "scientific and analytical ${ }^{30 "}$. For that reason also Friel 
made his characters name the new radio set (and perhaps science as a whole) after an old Pagan god and assimilate it with traditional Irish music and dance.

It would be tempting to continue the metaphor so as to consider Paganism, Christianity and science as a form of spiritual and societal Trinity of modern Ireland, even though such comparisons are necessarily not comprehensive and sufficient to define and determine the nature of a whole people or country in a given period of time. They turn out to be however the main three forces of the island or, to be more specific, the three principal pillars of its identity: science may represent Ireland's early $20^{\text {th }}$ century future - i.e. a part of her mid/late $20^{\text {th }}$ and $21^{\text {st }}$ century present; Paganism her vibrant, inspirational and occasionally controversial past; Christianity, the main focus of her identity since the first plantations of the $17^{\text {th }}$ century. The three complemented, and still complement, each other. Out of the tensions uniting or opposing those forces, something precious is born: the singularity of Ireland. Those emerging tensions are vectors of identity creation and, in a word, of Irishness - a syncretic and renewed Irishness, in the end accepting modernity as a complement to tradition(s), even if it meant that those traditions were to be renewed or reinvented. Perhaps the two examples studied in this paper will stand as yet another proof that Irishness, this prominent cultural singularity, is not only an artistic or spiritual fact: it is also a political one and, all things considered, the sheer offspring of the complex history of an island which is itself interwoven in the complex history of the world. 